\title{
The Significance of Teaching Academic English for English Language Learners
}

\author{
${ }^{* 1}$ Andriansyah Andriansyah, ${ }^{2}$ Ayyub Abdurrahman, ${ }^{3}$ Regina Rahmi \\ ${ }^{* 1}$ UIN Ar-Raniry Banda Aceh, Indonesia, E-mail: andriansyah.1@osu.edu \\ ${ }^{1}$ The Ohio State University, The United States \\ ${ }^{2}$ UIN Ar-Raniry Banda Aceh, Indonesia, E-mail: ayyub.ar@arraniry.ac.id, ayyubar070@gmail.com \\ ${ }^{3}$ STKIP Bina Bangsa Getsempena, Indonesia, regina@stkipgetsempena.ac.id
}

Submitted: 10/09/2019 Revised: 18/10/2019 Accepted: 07/11/2019

How to cite this article: Andriansyah, A., Abdurrahman, A., \& Rahmi, R. (2019). The significance of teaching academic English for English language learners. IJELR: International Journal of Education, Language, and

Religion, 1(1), 14-18. http://doi.org/10.35308/ijelr.v1i1.1719

\begin{abstract}
In my paper, I will discuss some topics related to supporting English Language Learners (ELLs) in developing their English as an academic language. Firstly, I describe the general issues of ELLs; including what languages are learned the most. Secondly, I provide some topics related to the effectiveness of instructional practice in ELs' teaching, type of instructional practices to support ELLs including some topics related to using L1 and L2 in teaching, the importance of teaching English at the younger aged or Teaching English to Young Learners. Lastly, I draw upon some issues related to the effective practice of teaching and learning for ELLs especially the importance of academic language, in particular to the English language learners. In addition, in this paper I use the term of ELLs and ELs, refers to the English Learners since the English Language Learners has been changing to be just English Learners (ELs) recently.
\end{abstract}

\section{Keywords}

academic English; English language learners; young learners; teaching English to young learners

\section{Introduction}

Language is one of semiotic resources of meaning making processes in the classroom in order to wire communication between a teacher and students and vice versa. A language is used as an instructional tool of classroom learning in all subjects in order to teachers to facilitate the teaching and learning process and for students to access knowledge. Students must be able to understand the main language used in the classroom such as English or other languages. Otherwise, special treatment must be provided to them in order to bridge the process of teaching and learning and meet the goal of teaching and learning. According to August and Hakuta (1997), several factors affect second language acquisition encompassing sociocultural contexts, first language proficiency, attitudes, personality, and perceived status. They regretfully stated that some problem remains the same recently; for instance, the inadequate process of data collection at the national level, unfriendly policies by the state and district, and other barriers. Some of them are inconsistent definitions, little agreement about indicators and inadequate data. Unfortunately, evidence found in the field that there are still lack access and existing curricular in teaching practices for ELs especially in developing their academic English. Nowadays, there are many thoughts and ideas being applied in order to support English language learners 
developing their ability in English such as Teaching English for Young Learners, using translanguaging, and so on.

Educators are required to recognize their students' needs in teaching, especially in teaching English for students who are not using English as their medium instruction, even more for students who are the Multilanguage users. By understand and recognizing their students in teaching, teachers can adapt and manipulate some methods, techniques, and factors during the teaching and learning process in order to meet the goal of their teaching, especially for the ELs. As an educator, the teacher needs to acknowledge the differences between the requirements for adult learners and those of young English language learners so that the target of teaching will be successfully met. In this chapter, I will discuss some ideas on how the importance of teaching English for Young Learners and its relation to the formal language.

There are different ways of children and adults absorb their information and new languages. Children have a tendency to sort out new words from actual objects especially in the early ages. According to Cameron, children" need very concrete vocabulary that connects with objects they can handle or see" (2001, p. 81). This condition is really required special attention from teachers as well as caregivers around the young learners in order to make the learning process more meaningful for them. In addition, Bourke (2006) noted that adult learners have the benefit of knowing the concepts of discourse, phonology, part of speech and other concepts of ideas through their knowledge of the first language they have.

Meanwhile, young learners do not have such concepts that make them more dilemmatic in learning other languages. (p. 280) In order to avoid this, which is suggested for a teacher to situated their students to find familiar topics for children such as their daily activities, their family and friends, etc. This condition will make them easier in processing the knowledge in another language since they have a clear conceptual image of these events or things. In line with this students are more engaged with a great motivation when learning, "students will be more motivated and build up their intrinsic motivation when they are involved in the activity in the classroom if it is meaningfully connected to their own real-world experience" (Andriansyah, 2012, p. 280). All of this form of acquiring knowledge and language mostly in the form of social language, then how about the academic language? However, there is still very limited evidence showing that teaching practices in academic English for the early age are successfully conducted, even though many educators believe that the early age to learn other languages is in its time.

\section{Discussion}

\section{The Use of Translanguaging in Teaching English Language Learners}

In practicing teaching and learning English for English learners, the use of English itself varies depends on the English teacher or where the process of teaching and learning acquire. "Spharim et al. (1999) determined how ELLs' native and second language proficiencies were related to their metalinguistic development in both languages and their achievement in English reading comprehension," (Klingner et al., 2006, p.120). On the other hands, "one study by Hansen, (1989) suggested that although English use at home can make a significant contribution to English language development, in general, English use at school probably plays an even more significant role in supporting higher levels of English language and literacy development" (Genesee et al., 2005, p. 8). Even though there are many quotes saying that using both languages at school can support the English proficiency of students, but some debate still occurs by saying that using English only can support English proficiency faster.

Also, related to the better practice of teaching for ELs, such as grammar, syntax, etc. In other words, other issues that might be raised is the type of instruction to be applied while teaching ELs, and or what to teach. In terms of teaching and learning, how their first language supports them in getting 
other languages is become the issue that is still debating until now. In this concerns, Klingner et al. stated that "students read English text but were encouraged to use Spanish as well as English in their discussions in order to get in depth in terms of comprehension the new language" (2006, p.113).

Another point supporting this statement described that the readers should be distinguished more by their way in using the language than how fluent they are in English, and the students who were good at one language usually good at others, the competence of Spanish owned by students makes the students better to create meaning in English and Spanish. Taken together, "ELLs are more successful when they participate in programs that are specially designed to meet their needs (ESL, bilingual, etc.) than in mainstream English classrooms and when the program is consistent throughout the student education" (Klingner et al., p.117).

Nonetheless, teachers who are teaching in multilingual classrooms students or environment have a big rule in making the process of learning more effective. As such, there are many ways or methods that can be applied by the teachers in teaching in multilingual classrooms such as, using scaffolding in teaching (Daniel, et al., 2017), applying some principles in supporting students with emergent bilingual and translangauging develop their languages while learning (Rowe, 2018). To make it clear, in his study, Rowe (2018), really support the existence of existing linguistic and literacy skills that students have and practice in their daily lives. Moreover, there are some principles of conditions in supporting translanguaging process in the classroom, namely; "valuing students' languages and cultures, modeling translanguaging, providing authentic opportunities for multilingual communication, inviting two-way translation, composing dual-language texts, and connecting students with bilingual or multilingual audiences." (Rowe, 2018, p. 31)

Rowe (2018) added that the teacher needs to make sure that students knew that they were invited and encourage to speak in whatever language they desired. This condition will make the students are more confident to present themselves in the classroom and can contribute better to their success in the classroom, (p.33). In line with this, interact with literacy by providing some books composed in multilanguages is really supported way and by that students feel more comfortable with their own language. Following the first principle of valuing students' languages and cultures, this activity was able to encourage and valuing students' cultures and languages as resources in the learning process. Then, having a picture to describe a situation on it to make more sense and easier for the students to understand the meaning is also effective in supporting multilanguage classroom students.

Hornberger and Link stated that "translanguaging refers to the way emergent bilinguals communicate and make meaning through the intermixing of their various linguistic repertoires," (2012, p.31). In line with this statement, Rowe (2018) emphasized that is really important to a teacher in multilanguage classrooms students to encourage their students to translate and share arguments with their partners. This is in line with his statement that mentioned: "students should be encouraged to use their translation skills as a resource as they read and discuss challenging texts and translation creates a space in which students can use their translanguaging skills as they move between languages." (p.32)

The term translanguaging itself was introduced by Williams (1994) "the act performed by bilinguals of accessing different linguistic features or various modes of what are described as autonomous languages in order to maximize the communicative potential" (Garcia, 2009, p. 140). In addition, Canagarajah (2011) has defined translanguaging as "the ability of multilingual speakers to shuttle between languages, treating the diverse languages that form their repertoire as an integrated system" (p. 401). Sayer (2013), in his research demonstrated how bilingual teachers and students mediated academic content and language ideologies through translanguaging strategies.

Hence, in order to support translanguaging pedagogies development, teachers need to encourage students and understand that it can support them in learning in the school. Daniel, et al., (2017) gave some great ideas on how teachers can support students develop their languages by using scaffolding in the classroom or school that use the language other than English.

Daniel, et al., mentioned that "as opposed to other types of literacy-learning strategies, curricular materials rarely include suggestions that support teachers in thinking about how they can engage their 
students in translanguaging in instruction," (2017, p.2). Moreover, this condition can be seen as the power of their own language that can enhance the self-esteem and confidence of the students. Moreover, in their study, Daniel, et al., tried to make "translanguaging as a norm and engage children in the rich interactions that can occur as they leverage their languages to make sense of text, teachers must think about scaffolding beyond just one lesson at a time in order to centralize translanguaging in their classroom" (2017, p.3).

Related to the above discussion, there are some concerns that might be considered from the previous researches related to translanguaging. The first thing is, whether the translanguaging will be an effective way of instruction in order to help children in developing their English literacy? Then how about the academic English development, does the translanguaging support ELLs in developing their academic English proficiency?

Then, from the What Works Clearinghouse's website (https://ies.ed.gov/ncee/wwc/), stated whether it is acceptable or not, or in other words, is it effective to allow children to use their mother tongue or just their language in the school? Lastly, as a developing idea from that is whether a literacy in your mother tongue language accepts other mother tongue languages especially in practicing during the classroom learning? Lastly, based on the explanation above, there are many ways to support English learners to meet the goal of teaching and learning process such as having more access to books, also practicing a translanguaging especially in the classroom teaching and learning context.

\section{The Importance of Teaching Academic English Instruction}

Being raised in a community that was not a native English language made me had less exposure to English resources. Learning English from the middle level made me having a lot of challenge to learn English like a new language from time to time. This condition made me and some friends in my period face challenge even after graduating from a high school level. These experiences made me think twice what was missing in the process of teaching and learning in the school, or what other factors missed in the process of learning the new languages. Generally, "Academic language proficiency is knowing and being able to use general and content-specific vocabulary, specialized or complex grammatical structures - all for the purpose of acquiring new knowledge and skills, interacting about a topic, or imparting information to others," (Bailey, 2007). In particular, some ideas of teaching and learning for ELs presented some ideas such as English for Young Learners, using translanguging during teaching and learning English, using some techniques or methods in teaching English like TPR (Total Physical Response) and so on. But, there are still many students struggling whenever they are given any kinds of English assessment and tests, and still many of them are failed on the test.

Nonetheless, based on my own experience advising student teachers at the university where I taught, and based on my experience observing English teachers in Aceh province, Indonesia, I learned that many of them did not even know what academic English was, let alone to teach them. The most important thing for them was just the question of how to use approaches that they thought were effective for English teaching. Although the idea may have been correct, it did not really address the gap between the teaching and learning practice in the classroom and between teaching and the various forms of assessment that were given to the students in measuring their English language learning success. What if there were better approaches that could be applied to academic English teaching, which combine both efforts to improve the overall English language skill and the particular academic English proficiency?

Educators are expected to have an effort in shifting this idea especially having more times to teach and develop academic language especially English academic language such as language structures; grammar and syntax which is collaborated and accommodated with other skills in academic English language such as listening, reading, writing, and speaking. Moreover, in the future, after graduating from their high school and going to their higher education level, students are expected to be mastered 
at any certain level of English in any subject that they are enrolled at the university. In this condition, the academic English language proficiency is really important for them.

The ideas above are really in line with what the teaching and learning focus in recent years. According to recommendation 4 on the What Works Clearinghouse (https://ies.ed.gov/ncee/wwc/) mentioned that the level of evidence on this matter is Low (primarily expert opinion). The research evidence-based is still rarely found in academia. In this case, educators are suggested to make sure the development of formal or academic English is a key factor to meet the goal of English learners, especially for Young Learners. Moreover, it can be concluded that the research on the instructional based and practices on the use of academic English is considered necessarily needed to be conducted.

\section{References}

Author. (2012). Transformative Learning: Teaching vocabulary to disadvantaged non-native language learners. Journal of International Education Research, 8(3), 279-282. https://doi.org/10.19030/jier.v8i3.7109

Bailey, A. L. (Ed.). (2007). The language demands of school: Putting academic English to the test. Yale University Press.

Canagarajah, S. (2011). Codemeshing in academic writing: Identifying teachable strategies of translanguaging. Modern Language Journal, 95, 401-417. https://d oi.org/10.1111/j.15404781.2011.01207

Daniel, S. M., Jiménez, R. T., Pray, L., \& Pacheco, M. B. (2017). Scaffolding to make translanguaging a classroom norm. TESOL Journal, https://doi.org/10.1002/tesj.361

Garcia, O. (2009). Bilingual education in the 21st century: A global perspective. Malden, MA: WileyBlackwell.

Genesee, F., Lindholm-Leary, K., Saunders, W., \& Christian, D. (2005). English language learners in US schools: An overview of research findings. Journal of Education for Students Placed at Risk, 10(4), 363-385.

Hornberger, N.H., \& Link, H. (2012). Translanguaging in today's classrooms: A biliteracy lens. Theory Into Practice, 51(4), 239- 247. https://doi.org/10.1080/00405841.2012.726051

Klingner, J. K., Artiles, A. J., \& Barletta, L. M. (2006). English language learners who struggle with reading: Language acquisition or LD?. Journal of Learning Disabilities, 39(2), 108-128.

Lavasani, M. G., \& Faryadres, F. (2011). Language learning strategies and suggested model in adults processes of learning second language. Procedia-Social and Behavioral Sciences, 15, 191-197.

Rowe, L. W. (2018). Say it in your language: Supporting translanguaging in multilingual classes. The Reading Teacher, 72(1), 31-38.

Sayer, P. (2013). Translanguaging, TexMex, and bilingual pedagogy: Emergent bilinguals learning through the vernacular. TESOL Quarterly, 47, 63-88. https://doi.org/10.1002/tesq.53 